American Journal of Applied Sciences 3 (1): 1655-1661, 2006

ISSN 1546-9239

(C) 2006 Science Publications

\title{
Evaluation and Beneficiation of Feldspar from Arkosic Sandstone in South Jordan for Application in the Ceramic Industry
}

\author{
Mousa Gougazeh \\ Natural Resources and Chemical Engineering Department, Faculty of Engineering \\ Tafila Technical University, P.O. Box 179, Tafila 66110, Jordan
}

\begin{abstract}
The main purpose of the present study was to investigate the beneficiation and upgrading processes of a Jordanian feldspar ores to be finally implemented in the ceramic industry. The experimental work was conducted to evaluate the role of particle size distribution, chemical composition, mineral content and the magnetic impurities $\left(\mathrm{Fe}_{2} \mathrm{O}_{3}+\mathrm{TiO}_{2}\right.$ contents). The beneficiation of the $500-45 \mu \mathrm{m}$ fractions, which constitutes about $30 \%$ of the ore, assaying $10.9 \% \mathrm{Al}_{2} \mathrm{O}_{3}$, equivalent to approximately ca $56 \%$ feldspar, with a mean of magnetic content of $0.95 \%$ iron and titanium oxides. The relationship of potassic-to-sodic feldspar amounts to approximately 18:1 in the feldspar fraction. High intensity magnetic separation and froth flotation test work was carried out, in order to decrease the iron contamination and increase the feldspar content. Magnetic separation alone decreased the iron contents of the feed to a range between 0.10 and $0.12 \%$ iron oxides with an average yield greater than $85 \%$. Flotation with HF provided a feldspar recovery of $45-55 \%$ with a concentrates assaying $17-$ $17.35 \% \mathrm{Al}_{2} \mathrm{O}_{3}$. Iron contents were decreased from $0.46-0.68 \%$ to $0.17-0.23 \%$.
\end{abstract}

Key words: Salib formation, feldspar ore, scrubbing, beneficiation, froth flotation, collector, high gradient magnetic separation

\section{INTRODUCTION}

There is a great need in Jordan for the development of a new process for beneficiation and concentration of kaolin and feldspar from the kaolinitic sand-arkosic sandstones to sustain the demand of these minerals in domestic industry and also to open the market for the export of the raw materials itself and secure new sources of hard currency needed by Jordan.

The demand for feldspar as a raw material for industrial applications especially in ceramic manufactures is continuously increasing. In Jordan, the traditional sources of feldspar, pegmatitic and weathered granites are located in the southern Jordan; in the Aqaba region and feldspathic sand (arkosic sandstone). In south Jordan, extensive deposits of arkosic sandstone (Salib Formation) are present. In this formation, there are three major industrial mineralskaolin-potash feldspar and quartz. They may be of economic value and possibly suitable for commercial uses. The arkosic sandstone (Lower Cambrian) can be traced as a mappable from the Ram area in south Jordan along the eastern side of the Wadi Araba as for as to the Dead Sea ${ }^{[1]}$. The thickness of the Salib formation between $20 \mathrm{~m}$ and $60 \mathrm{~m}$ shows relatively small variation from south Jordan to the central Wadi Araba; it increases considerably from the area of Feinan [(ancient copper mines), in ancient time, there are many activities in mining and extracting copper as indicated by the slags in Feinan and other localities] northwards to the Dead Sea where it attains very soon a thickness of about $200 \mathrm{~m}$. The locations stands out due to its bordering on the primary rock formations of south Jordan, which consist of granite and gneiss rich in feldspar and which were the source of arkose deposits that occur in south Jordan. This implies an increase in the imports of high quality raw material. It became therefore imperative to look at other types of deposits, such as this arkose, a sedimentary rock originated from the origin of granites, where the resulting particles were deposited after a hydraulic transport.

The first attempt was made to upgrade potassium feldspar (K-Feldspar) from arkosic sandstone deposits of South Jordan as a semi processing scale ${ }^{[2]}$. The present work intends to fill this lack of information and reports on methods for opening up feldspar deposits and specifies the requirements to be met by K-feldspar products for varying industrial applications. The exploration and evaluation of raw materials for industrial uses is a very important step for encouraging local industries. In addition, it participates in forming a strong and healthy economy. There are many industrial raw material which are imported for local market, although, some of these may be present but not been evaluated.

The main aims of the present study were to evaluate the arkosic sandstone in selected locations: Ayn Al Hashim, South Al-Quweira and Wadi Numira 
from south Jordan for its commercial feldspar content, and to determine the best separation method for beneficiation, which gives the best type of feldspar to meet the specification of ceramic and other industries.

Locally, feldspars are widely used in ceramic, glass, sanitary and porcelain. Demands are mostly met by imports. In the crude or raw state, these deposits are of low quality, due to the presence of impurities such as iron oxides and mica minerals which prevent their application in the ceramic and other industries.

\section{MATERIALS AND METHODS}

Three representative samples of arkosic sandstone were obtained from Ayn Al Hashim, South Quweira and Wadi Numira deposits by channel sampling, each sample weighted about $50 \mathrm{~kg}$. The original samples were completely oven-dried to $105^{\circ} \mathrm{C}$. They were first crushed gently by a jaw crusher in order to separate the different grains from each other. Each sample was mixed well several times to form a composite sample and each of these composite samples was subjected to a Retsch sample splitter PT 1000, and finally a quarter was chosen for beneficiation process.

Arkosic sandstone samples were ground using wet grinding process (Rod mill machine) in order to liberate and release the potassic feldspar minerals from other gangue, mainly quartz. These samples then sieved by wet sieving into size fractions $(>500 \mu \mathrm{m}, 500-250 \mu \mathrm{m}$, 250-106 $\mu \mathrm{m}$ and 106-45 $\mu \mathrm{m}$ and $<25 \mu \mathrm{m}$.

Slime (overflow) was removed from Ayn Al Hashim, South Quweira and Wadi Numira samples using a hydrocyclone at a cut off of $45 \mu \mathrm{m}$ after grinding the whole sample by rod mill to $500 \mu \mathrm{m}$.

Separation and beneficiation methods of feldspar minerals from other constituents of Ayn Al Hashim, South Quweira and Wadi Numira rocks was done after the minerals of sand were liberated and classified.

Magnetic separation was carried out on Ayn Al Hashim, South Quweira and Wadi Nimira samples (was carried out on these deposits) after slime removal by a hydrocyclone at cut off limit of $45 \mu \mathrm{m}$. The beneficiation tests were done on the $500-45 \mu \mathrm{m}$ product (in which the feldspar is naturally concentrated), with a wet or dry feed, using a Jones matrix model wet high intensity magnetic separation (WHIMS) from KHD Humboldt-Wedag, Germany and high intensity induced roll magnetic separator (IMR) from Krupp Industrie and Stahlbau of Duisburg, Germany at different intensities of the magnetic filed, the magnetic filed intensity was varied from 12000 gauss to 18000 gauss.

Froth flotation process was used for beneficiation of the 45-500 $\mu \mathrm{m}$ fractions (feed) for the representative samples of Ayn Al Hashim, South Quweira and Wadi Nimira, in which the feldspar is naturally concentrated. The flotation tests were conducted using a Denver D12 flotation machine.
The chemical analysis of the raw materials and the various grain size fractions as well as the final feldspar products was made by X-ray fluorescence.

\section{RESULTS AND DISCUSSION}

Sample characterization: The mineralogical studies showed that intergrown feldspar/quartz particles were practically absent in sizes smaller than $500 \mu \mathrm{m}$. A very low content of mica was also noted in the $45-500$ fractions $^{[2]}$.

The - $45 \mu \mathrm{m}$ fraction is a kaolin with $67 \%$ kaolinite, 18 mica, $11 \%$ quartz and $7 \%$ K-feldspar (microcline and orthoclase), with a possible ceramic application. In order to avoid slime coating in the separation processes, the $-45 \mu \mathrm{m}$ fraction was removed.

The $+45 \mu \mathrm{m}$ material was classified into narrow size fractions, in which the K-feldspar contents were determined. Many wet screen tests for Ayn Al Hashim, South Quweira and Wadi Numira samples were carried out to examine the effect of the different size fraction on the content of K-feldspar. A natural concentration of feldspar can be observed between 45 and $500 \mu \mathrm{m}$. The size distribution of the studied representative samples is illustrated in Fig. 1. It is clear, that the percentages of 45-500 $\mu \mathrm{m}$ size fractions are about 42, 46 and 37 for Ayn Al Hashim, South Quweira and Wadi Numira respectively.



The chemical analysis of three representative samples divided into three relevant size fractions, was determined by X-ray fluorescence (XRF) for Ayn Al Hashim, South Quweira and Wadi Numira is presented in Tables 1, 2 and 3 respectively.

The grain size analysis showed that $47-60 \%$ of the arkosic sandstone is less than $500 \mu \mathrm{m}$ in diameter. 
Am. J. Appl. Sci., 3 (1): 1655-1661, 2006

Table 1: Size analysis and chemical composition of a representative arkose sample from Ayn Al Hashim deposit

\begin{tabular}{lccccccccccc}
\hline $\begin{array}{l}\text { Size fraction } \\
{[\mu \mathrm{m}]}\end{array}$ & $\begin{array}{c}\mathrm{Mass} \\
{[\%]}\end{array}$ & $\begin{array}{c}\mathrm{SiO}_{2} \\
{[\%]}\end{array}$ & $\begin{array}{c}\mathrm{TiO}_{2} \\
{[\%]}\end{array}$ & $\begin{array}{c}\mathrm{Al}_{2} \mathrm{O}_{3} \\
{[\%]}\end{array}$ & $\begin{array}{c}\mathrm{Fe}_{2} \mathrm{O}_{3} \\
{[\%]}\end{array}$ & $\begin{array}{c}\mathrm{MnO} \\
{[\%]}\end{array}$ & $\begin{array}{c}\mathrm{MgO} \\
{[\%]}\end{array}$ & $\begin{array}{c}\mathrm{CaO} \\
{[\%]}\end{array}$ & $\begin{array}{c}\mathrm{Na}_{2} \mathrm{O} \\
{[\%]}\end{array}$ & $\begin{array}{c}\mathrm{K}_{2} \mathrm{O} \\
{[\%]}\end{array}$ & $\begin{array}{c}\mathrm{LOI} \\
{[\%]}\end{array}$ \\
\hline$>500$ & 48.80 & 93.60 & 0.15 & 3.12 & 0.15 & 0.00 & 0.01 & 0.42 & 1.05 & 0.78 & 0.18 \\
$500-45$ & 42.08 & 78.75 & 0.24 & 10.73 & 0.92 & 0.01 & 0.02 & 0.95 & 0.78 & 8.06 & 0.31 \\
$<45$ & 9.12 & 46.34 & 0.32 & 33.85 & 3.11 & 0.01 & 0.03 & 1.38 & 1.46 & 5.86 & 8.42 \\
Original sample & 100.0 & 84.35 & 0.21 & 9.29 & 0.68 & 0.01 & 0.01 & 0.32 & 0.72 & 3.43 & 1.54 \\
\hline
\end{tabular}

Table 2: Size analysis and chemical composition of a representative arkose sample from South Quweira deposit

\begin{tabular}{lccccccccccc}
\hline $\begin{array}{l}\text { Size fraction } \\
{[\mu \mathrm{m}]}\end{array}$ & $\begin{array}{c}\text { Mass } \\
{[\%]}\end{array}$ & $\begin{array}{c}\mathrm{SiO}_{2} \\
{[\%]}\end{array}$ & $\begin{array}{c}\mathrm{TiO}_{2} \\
{[\%]}\end{array}$ & $\begin{array}{c}\mathrm{Al}_{2} \mathrm{O}_{3} \\
{[\%]}\end{array}$ & $\begin{array}{c}\mathrm{Fe}_{2} \mathrm{O}_{3} \\
{[\%]}\end{array}$ & $\begin{array}{c}\mathrm{MnO} \\
{[\%]}\end{array}$ & $\begin{array}{c}\mathrm{MgO} \\
{[\%]}\end{array}$ & $\begin{array}{c}\mathrm{CaO} \\
{[\%]}\end{array}$ & $\begin{array}{c}\mathrm{Na}_{2} \mathrm{O} \\
{[\%]}\end{array}$ & $\begin{array}{c}\mathrm{K}_{2} \mathrm{O} \\
{[\%]}\end{array}$ & $\begin{array}{c}\mathrm{LOI} \\
{[\%]}\end{array}$ \\
\hline$>500$ & 38.62 & 94.10 & 0.35 & 2.42 & 0.11 & 0.00 & 0.01 & 0.48 & 0.95 & 0.68 & 0.16 \\
$500-45$ & 45.82 & 79.65 & 0.28 & 9.20 & 0.42 & 0.01 & 0.02 & 1.42 & 0.85 & 7.12 & 0.26 \\
$<45$ & 15.56 & 49.84 & 0.42 & 31.20 & 1.65 & 0.01 & 0.03 & 1.88 & 1.20 & 5.30 & 8.12 \\
Original sample & 100.0 & 86.45 & 0.25 & 8.24 & 0.46 & 0.00 & 0.00 & 0.24 & 0.43 & 2.93 & 1.34 \\
\hline
\end{tabular}

Table 3: Size analysis and chemical composition of a representative arkose sample from Wadi Numira deposit

\begin{tabular}{lccccccccccc}
\hline $\begin{array}{l}\text { Size fraction } \\
{[\mu \mathrm{m}]}\end{array}$ & $\begin{array}{c}\mathrm{Mass} \\
{[\%]}\end{array}$ & $\begin{array}{c}\mathrm{SiO}_{2} \\
{[\%]}\end{array}$ & $\begin{array}{c}\mathrm{TiO}_{2} \\
{[\%]}\end{array}$ & $\begin{array}{c}\mathrm{Al}_{2} \mathrm{O}_{3} \\
{[\%]}\end{array}$ & $\begin{array}{c}\mathrm{Fe}_{2} \mathrm{O}_{3} \\
{[\%]}\end{array}$ & $\begin{array}{c}\mathrm{MnO} \\
{[\%]}\end{array}$ & $\begin{array}{c}\mathrm{MgO} \\
{[\%]}\end{array}$ & $\begin{array}{c}\mathrm{CaO} \\
{[\%]}\end{array}$ & $\begin{array}{c}\mathrm{Na}_{2} \mathrm{O} \\
{[\%]}\end{array}$ & $\begin{array}{c}\mathrm{K}_{2} \mathrm{O} \\
{[\%]}\end{array}$ & $\begin{array}{c}\mathrm{LOI} \\
{[\%]}\end{array}$ \\
\hline$>500$ & 52.12 & 94.35 & 0.20 & 2.32 & 0.21 & 0.00 & 0.02 & 0.51 & 0.88 & 0.88 & 0.16 \\
$500-45$ & 37.17 & 80.13 & 0.48 & 9.25 & 0.76 & 0.01 & 0.03 & 0.78 & 1.56 & 6.83 & 0.26 \\
$<45$ & 10.71 & 48.20 & 0.62 & 30.18 & 2.95 & 0.04 & 0.08 & 1.45 & 1.82 & 7.20 & 7.42 \\
Original sample & 100.0 & 87.20 & 0.18 & 8.34 & 0.53 & 0.02 & 0.02 & 0.16 & 0.65 & 2.23 & 1.14 \\
\hline
\end{tabular}

The fine fraction $(-45 \mu \mathrm{m})$ reaches a higher percentage in the Quweira samples (15.5\%) and the lower percentage in Ayn Al Hashim (9\%).

From the chemical standpoint, the 45-500 $\mu \mathrm{m}$ size fractions (feed samples) of the Ayn Al Hashim, South Quweira and Wadi Numira deposits, which constitute about 42,46 and $37 \%$ respectively, assaying 10.73, 9.20 and $9.25 \%$ of $\mathrm{Al}_{2} \mathrm{O}_{3}$, respectively equivalent to approximately $54 \%$ feldspar (Ayn Al Hashim) and 51 $\%$ feldspar for each South Quweira and Wadi Numira, with an average of iron content of 0.9, 0.4 and $0.7 \%$ iron oxides, respectively.

The grain size analysis, and the results of the mineralogical and chemical analysis indicate that the arkosic sandstone from Ayn Al Hashim, South Quweira and Wadi Numira areas contain higher amount of potassium feldspar and low amount of $\mathrm{Fe}_{2} \mathrm{O}_{3}$.

The $\mathrm{SiO}_{2} \%$ increases with increasing grain size indicating that quartz is concentrated in the large size fraction (more than $500 \mu \mathrm{m}$ ). The $\mathrm{K}_{2} \mathrm{O}$ and $\mathrm{Al}_{2} \mathrm{O}_{3}$ increase with decreasing grain size indicating that the feldspar and kaolin are concentrated in the finer fraction $(-500 \mu \mathrm{m})$. In addition, the feldspar minerals present in the samples are broken down, altered and fractured and can be easily ground into smaller size using any milling machine.

The results also indicate that the percentage of the $\mathrm{Fe}_{2} \mathrm{O}_{3}$ is low and ranges from $0.11 \%$ in the $+500 \mu \mathrm{m}$ size fraction to $0.95 \%$ in the $500-45 \mu \mathrm{m}$ size fraction in the arkosic sandstone. The $\mathrm{Fe}_{2} \mathrm{O}_{3}$ increase with decreasing size fraction, and is concentrated mainly in the fine fraction of $<45 \mu \mathrm{m}$.

The beneficiation of feldspar from arkosic sandstone should take in consideration that the small size fraction $(-500 \mu \mathrm{m})$ contain the highest amount of feldspar and that feldspar is friable and easily ground to small grains if it is subjected to grinding.

Feldspar beneficiation: The aim of this work is to obtain feldspar suitable for ceramic and other industries. The chemical analysis of the representative samples of Ayn Al Hashim, South Quweira and Wadi Numira areas in the above sections, indicate that these materials cannot be used as it is in industry. This due to its high $\mathrm{SiO}_{2}$ content, which is exceeding $85 \%$. It is obvious that for producing feldspar with higher $\mathrm{K}_{2} \mathrm{O}$ and lower $\mathrm{Fe}_{2} \mathrm{O}_{3}$ contents, beneficiation and upgrading must be used. The required end product after processing could be a high grade one with $\mathrm{K}_{2} \mathrm{O}$ of minimum $10-13 \%$ and $\mathrm{Fe}_{2} \mathrm{O}_{3}$ of maximum $0.15-0.70 \%{ }^{[3,4]}$. To reach this grade we must choose a process to separate the arkosic sandstone constituents (quartz) to obtain a high $\mathrm{K}_{2} \mathrm{O}$. This could be accomplished by froth flotation technique.

However, the separation and concentration operation requires size reduction by crushing and grinding to liberate the different minerals.

Slime removal by hydrocyclone: In order to avoid slime coating in the separation processes, slime was removed from Ayn Al Hashim, South Quweira and Wadi Numira samples using a hydrocyclone at a cutt 
off limit of $45 \mu \mathrm{m}$ after grinding the whole samples by rod mill to $500 \mu \mathrm{m}$. The $<45 \mu \mathrm{m}$ fraction from the three studied deposits will be beneficiated and upgraded as kaolin concentrate in another study. This is a common procedure in industry. The results slime removals are represented in Fig. 2.



Fig. 2: Weight percent of the overflow (slime) and underflow materials using a hydrocyclone with a cut off limit 45 $\mu \mathrm{m}$ for Ayn Al Hashim, South Quweira and Wadi Numira deposits

The results indicate that South Quweira sample have higher slime content $(15.56 \%)$ than Ayn Al Hashim sample $(9.12 \%)$ and Wadi Numira sample (10.71).

Magnetic separation: The results of magnetic and non-magnetic materials separated by magnetic separation are showed in Fig. 3.

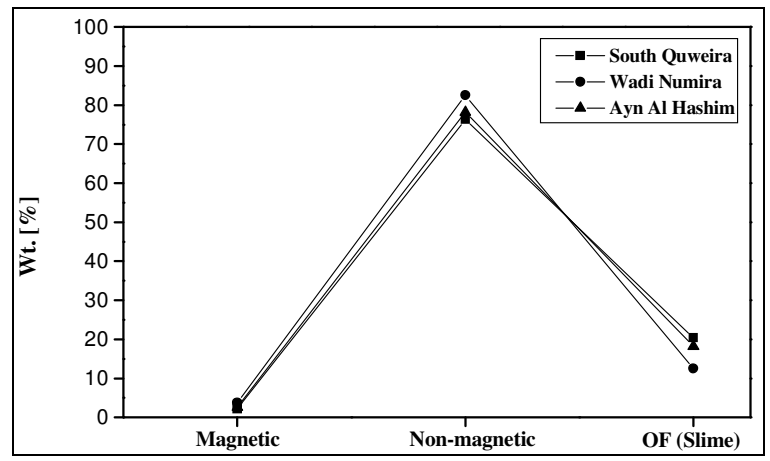

Fig. 3: Weight percent of magnetic, nonmagnetic and OF (slime) materials for the three studied deposits (Ayn Al Hashim, South Quweira and Wadi Numira)

The results show that magnetic materials are low for all three studied deposits and range between 2 and 4 $\%$ of the sample, while non-magnetic materials separated from South Quweira (76.3\%) and Ayn Al
Hashim $(78.2 \%)$ are lower than those from Wadi Numira $(82.5 \%)$.

Also the beneficiation and upgrading tests with a wet or dry feed were carried out on $-500+45 \mu \mathrm{m}$ products and the $-500+250 \mu \mathrm{m},-250+106 \mu \mathrm{m}$ and $106+45 \mu \mathrm{m}$ fractions of all three representative samples from the three studied deposits. To illustrate a better comparison of the wet and dry processes, size distribution, yields and magnetic minerals or magnetic impurities (iron and titanium content) of the different size fractions are plotted in Figs. 4 to 9.

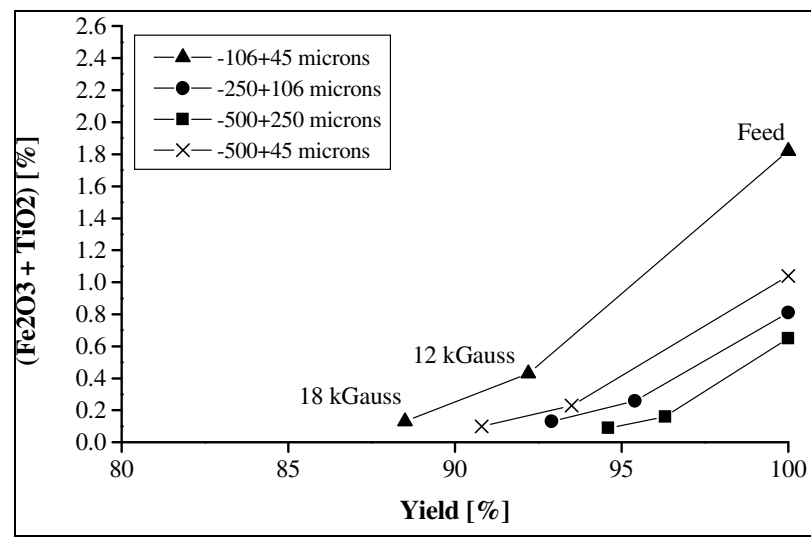

Fig. 4: Results obtained with a dry feed of Ayn Al Hashim deposit, by varying the magnetic field intensity on the Induced Roll magnetic separator



Fig. 5: Results obtained with a dry feed of South Quweira deposit, by varying the magnetic field intensity on the Induced Roll magnetic separator

The results obtained with the Jones matrix and the Induced Roll separators, a similarity can be seen for all the wet feed fractions and the dry feed particles coarser than $106 \mu \mathrm{m}$. 
At 12000 gauss, magnetic content between 0.11 and $0.45 \%$, corresponding to yield values of about $97 \%$ was achieved; at 18000 gauss the iron oxides in the

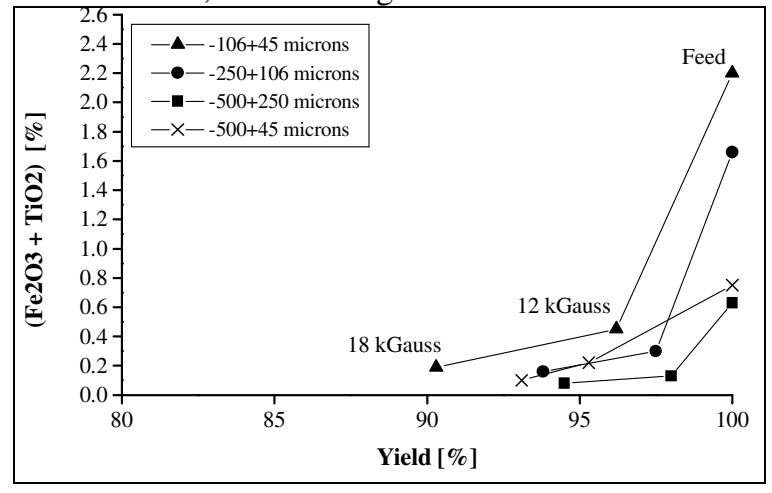

Fig. 6: Results obtained with a dry feed of Wadi Numira deposit, by varying the magnetic field intensity on the Induced Roll magnetic separator



Fig. 7: Results obtained with a wet feed of Ayn Al Hashim deposit, by varying the magnetic field intensity on a Jones matrix magnetic separator

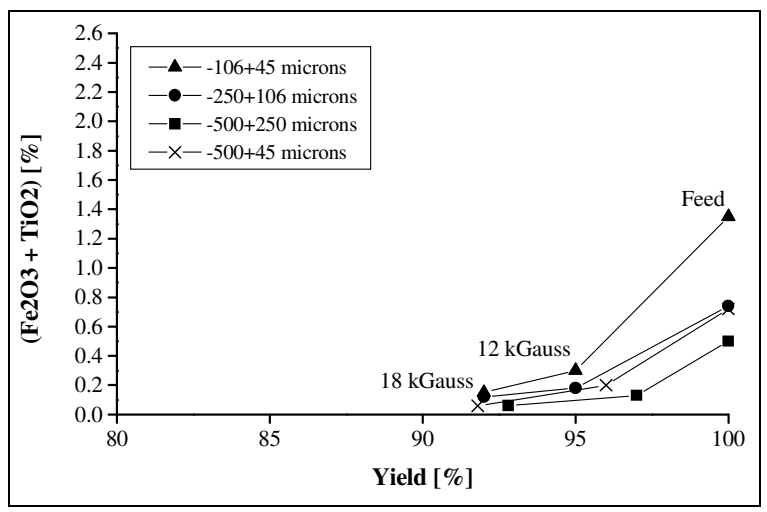

Fig. 8: Results obtained with a wet feed of South Quweira deposit, by varying the magnetic field intensity on a Jones matrix magnetic separator

final product were reduced to values between 0.05 and $0.18 \%$. However, for the finest size fractions $(-106+45$ $\mu \mathrm{m})$, the achievement of this target for the magnetic content with the induced Roll separator, implied a significant reduction of the yield (ca $88 \%$ ).

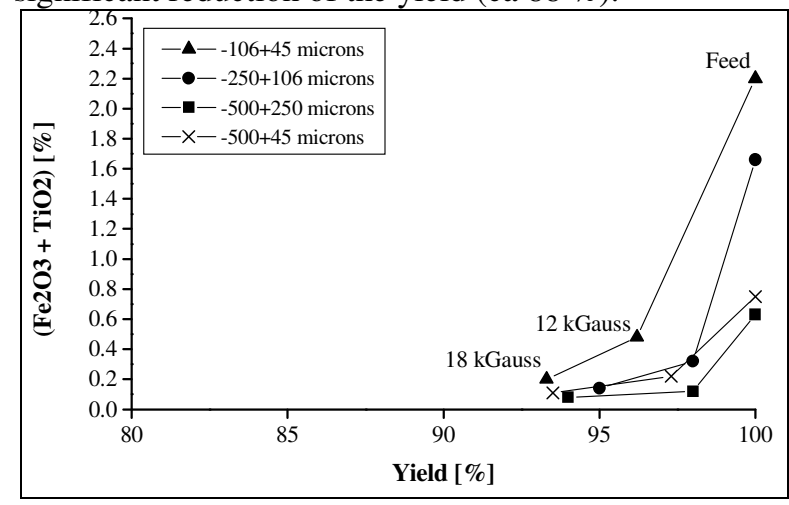

Fig. 9: Results obtained with a wet feed of Wadi Numira deposit, by varying the magnetic field intensity on a Jones matrix magnetic separator

As a contribution for the understanding of this behaviour, it seem that these results are mainly due to an being related to an intrinsic feature of the treatment by magnetic separation, being related to an indiscriminate adhesion of non-magnetic particles to the magnetic fraction, which is enhanced in the finest sizes.

The graphs of Figs. 4 - 9, also illustrate a typical behaviour of well-liberated feed samples. This permits the removal of magnetic materials $\left(\mathrm{Fe}_{2} \mathrm{O}_{3}+\mathrm{TiO}_{2}\right.$ oxides), without significant losses of material.

Froth flotation: The flotation of magnetic minerals was efficiently achieved with sulfonate collectors (Aero 801 and 825). A rougher and a scavenger stage were used. Both collectors were added to each stage (about $200 \mathrm{~g} / \mathrm{t}$ ) and about $60 \mathrm{~g} / \mathrm{t}$ of MIBC used as frother.

The feldspar minerals and quartz were separated from each other by flotation of feldspar minerals and depression of quartz minerals. Feldspar was floated using tallow amine acetate at a $\mathrm{pH} 2.5^{[5,6]}$, with a pulp density of $30 \%$. Hydrofluoric acid (HF) was used as quartz depressant. This is accomplished by adding about $1400 \mathrm{~g} / \mathrm{t}$ of $40 \%$ concentrated HF. No frother was added and the collector dosage was optimized at $800 \mathrm{~g} / \mathrm{t}$ of Armolote 820.

The final product of flotation process were $\mathrm{K}$ feldspar minerals concentrate as end product and quartz mineral as a by product.

The percentage of feldspar and quartz, in addition to slime $(\mathrm{OF})$ and magnetic materials are illustrated in Fig. 10. The results showed that Ayn Al Hashim (37 \%), South Quweira (36\%) and Wadi Numira (35\%) have approximately equal percent of feldspar.

The results of the chemical analysis of the original sample, slime (OF), magnetic and non-magnetic 
materials, feldspar and quartz products beneficiated from Ayn Al-Hashim, South Quweira and Wadi Numira are listed in Tables 4, 5 and 6 respectively.

Table 4: Chemical analysis of slime (OF), magnetic, non-magnetic, feldspar and quartz materials separated by beneficiation process for Ayn $\mathrm{Al} \mathrm{Hashim} \mathrm{deposit}$

\begin{tabular}{lcccccc}
\hline Oxide [\%] & Original sample & Slime (OF) & Magnetic & Non-Magnetic & Quartz & Feldspar \\
\hline $\mathrm{SiO}_{2}$ & 84.35 & 53.98 & 72.57 & 71.18 & 98.01 & 69.38 \\
$\mathrm{TiO}_{2}$ & 0.21 & 0.61 & 2.28 & 0.08 & 0.02 & 0.04 \\
$\mathrm{Al}_{2} \mathrm{O}_{3}$ & 9.29 & 37.42 & 11.07 & 16.42 & 0.81 & 17.35 \\
$\mathrm{Fe}_{2} \mathrm{O}_{3}$ & 0.68 & 1.82 & 7.34 & 0.29 & 0.10 & 0.23 \\
$\mathrm{MnO}$ & 0.01 & 0.01 & 0.02 & 0.00 & 0.00 & 0.03 \\
$\mathrm{MgO}$ & 0.01 & 0.02 & 0.03 & 0.00 & 0.00 & 0.07 \\
$\mathrm{CaO}$ & 0.32 & 0.81 & 0.28 & 0.14 & 0.10 & 0.15 \\
$\mathrm{Na} 2 \mathrm{O}$ & 0.72 & 0.65 & 1.23 & 2.04 & 0.32 & 1.52 \\
$\mathrm{~K}_{2} \mathrm{O}$ & 3.43 & 3.72 & 4.23 & 9.48 & 0.61 & 10.86 \\
$\mathrm{Total}$ & 99.02 & 99.04 & 99.05 & 99.63 & 99.97 & 99.63 \\
\hline
\end{tabular}

Table 5: Chemical analysis of slime (OF), magnetic, non-magnetic, feldspar and quartz materials separated by beneficiation process for South Quweira deposit

\begin{tabular}{lcccccc}
\hline Oxide [\%] & Original sample & Slime (OF) & Magnetic & Non-Magnetic & Quartz & Feldspar \\
\hline $\mathrm{SiO}_{2}$ & 86.45 & 54.83 & 70.05 & 73.54 & 98.23 & 70.03 \\
$\mathrm{TiO}_{2}$ & 0.25 & 0.76 & 2.67 & 0.14 & 0.03 & 0.10 \\
$\mathrm{Al}_{2} \mathrm{O}_{3}$ & 8.24 & 36.32 & 11.28 & 15.51 & 0.73 & 17.22 \\
$\mathrm{Fe}_{2} \mathrm{O}_{3}$ & 0.46 & 1.71 & 6.32 & 0.21 & 0.03 & 0.17 \\
$\mathrm{MnO}$ & 0.00 & 0.02 & 0.15 & 0.02 & 0.01 & 0.01 \\
$\mathrm{MgO}$ & 0.00 & 0.03 & 0.45 & 0.05 & 0.01 & 0.09 \\
$\mathrm{CaO}$ & 0.24 & 1.10 & 0.61 & 0.26 & 0.08 & 0.13 \\
$\mathrm{Na} 2 \mathrm{O}$ & 0.43 & 0.32 & 1.52 & 1.60 & 0.10 & 1.24 \\
$\mathrm{~K}_{2} \mathrm{O}$ & 2.93 & 4.11 & 5.95 & 8.56 & 0.18 & 10.61 \\
$\mathrm{Total}$ & 99.00 & 99.20 & 99.00 & 99.89 & 99.40 & 99.60 \\
\hline
\end{tabular}

Table 6: Chemical analysis of slime (OF), magnetic, non-magnetic, feldspar and quartz materials separated by beneficiation process for Wadi Numira deposit

\begin{tabular}{lcccccc}
\hline Oxide [\%] & Original sample & Slime $(\mathrm{OF})$ & Magnetic & Non-Magnetic & Quartz & Feldspar \\
\hline $\mathrm{SiO}_{2}$ & 87.20 & 55.43 & 71.97 & 72.73 & 99.46 & 71.64 \\
$\mathrm{TiO}_{2}$ & 0.18 & 0.56 & 1.84 & 0.21 & 0.02 & 0.08 \\
$\mathrm{Al}_{2} \mathrm{O}_{3}$ & 8.34 & 27.42 & 10.05 & 16.02 & 0.30 & 17.01 \\
$\mathrm{Fe}_{2} \mathrm{O}_{3}$ & 0.53 & 3.82 & 8.02 & 0.23 & 0.01 & 0.20 \\
$\mathrm{MnO}$ & 0.02 & 0.02 & 0.02 & 0.02 & 0.02 & 0.03 \\
$\mathrm{MgO}$ & 0.02 & 1.78 & 1.81 & 0.05 & 0.01 & 0.07 \\
$\mathrm{CaO}$ & 0.16 & 1.53 & 0.18 & 0.04 & 0.03 & 0.15 \\
$\mathrm{Na} 2 \mathrm{O}$ & 0.65 & 1.87 & 0.30 & 1.21 & 0.12 & 0.34 \\
$\mathrm{~K}_{2} \mathrm{O}$ & 2.23 & 7.22 & 4.83 & 9.03 & 0.01 & 10.21 \\
$\mathrm{Total}$ & 99.33 & 99.65 & 99.02 & 99.54 & 99.98 & 99.73 \\
\hline
\end{tabular}

The results of Tables 4 to 6 indicate that high quality products of feldspar were achieved by using flotation process (HF-acid). In the investigated raw samples, the $\mathrm{Fe}_{2} \mathrm{O}_{3}$ contents for Ayn Al Hashim (0.68 
$\%)$, South Quweira $(0.46 \%)$ and Wadi Numira $(0.53 \%)$ were decreased in the beneficiated feldspar to 0.23 , 0.17 and $0.20 \%$, respectively while $\mathrm{TiO}_{2}$ contents were decreased from $0.21,0.25$, and $0.18 \%$ to $0.04,0.10$ and

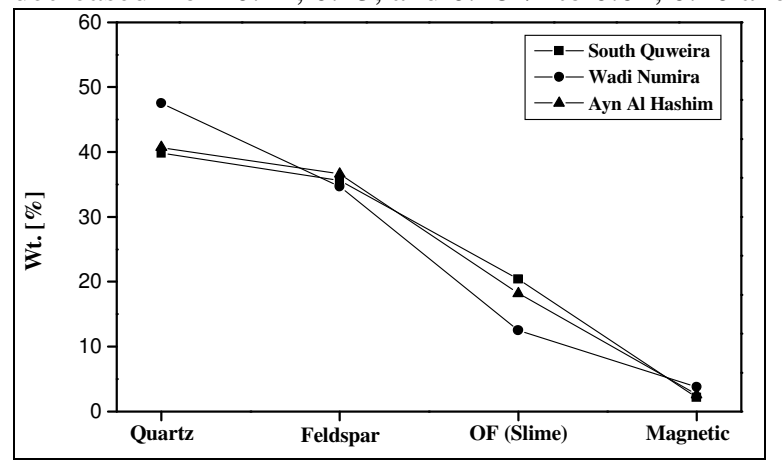

Fig 10: Weight percentage of quartz, feldspar, slime (OF) and magnetic minerals for the three studied deposits (Ayn Al Hashim, South Quweira and Wadi Numira)

$0.08 \%$, respectively. The $\mathrm{K}_{2} \mathrm{O}$ content reaches the highest percentage in the beneficiated feldspar, which is about 10.86, 10.61 and $10.21 \%$ for the investigated samples from Ayn Al Hashim, South Quweira and Wadi Numira deposits, respectively. The $\mathrm{Al}_{2} \mathrm{O}_{3}$ content in the beneficiated feldspar from Ayn Al Hashim, South Quweira and Wadi Numira deposits is about 17.35, 17.22 and $17 \%$, respectively, close up to $20 \%$ for pure feldspar. Rational mineralogical composition analysis of feldspar products from the three studied deposits has approximately equal percent of feldspar [87 \% (Ayn Al Hashim), $86 \%$ (South Quweira) and $85 \%$ (Wadi Numira)], it was concluded that the final products of feldspar beneficiated from these deposits are the source for K-feldspar product.

\section{CONCLUSION}

The present study for K-feldspar beneficiation from arkosic sandstone in three localities in South Jordan (Ayn Al Hashim, South Quweira and Wadi Numira) came the following conclusions: A huge deposit of arkosic sandstone with a large extension exists in south Jordan.

The arkosic sandstone is composed of quartz $\left(\mathrm{SiO}_{2}\right)$, which is concentrated in the coarse size fraction $(+500 \mu \mathrm{m})$, while the K-feldspar, kaolin and iron and titanium oxides are concentrated in the fine fraction $(-500 \mu \mathrm{m})$.

Scrubbing, a natural pre-concentration of feldspar occurs in the $(-500+45 \mu \mathrm{m})$ size fraction. A recovery of 42,46 and $37 \%$ of the ore deposits by weight was achieved, to give products with feldspar content of approximately $54 \%$ (Ayn Al Hashim) and $46 \%$ for each South Quweira and Wadi Numira.
Beneficiation of the $(-500+45 \mu \mathrm{m})$ size fraction using magnetic separation. The magnetic impurities $\left(\mathrm{Fe}_{2} \mathrm{O}_{3}+\mathrm{TiO}_{2}\right.$ contents) could be reduced from $1.04 \%$, $0.72 \%$ and $0.75 \%$ to $0.09 \%, 0.08 \%$ and $0.10 \%$ for Ayn Al Hashim, South Quweira and Wadi Numira, respectively. With a magnetic field of 18000 gauss, the yields reached for both the dry and the wet feeds were about $94 \%$, except for the dry material less than 106 $\mu \mathrm{m}$, where it was only $88 \%$.

The percent recovery of $\mathrm{K}_{2} \mathrm{O}$ in the feldspar products beneficiated and concentrated by flotation tests was highest and reached $88-90 \%$ for the three studied deposits. These products contained about 0.17 $0.23 \%$ total iron oxides, which satisfy the requirements of the ceramic industry.

K-feldspar ores beneficiated from arkosic sandstone of the three studied deposits would be classified as high grade with class 2-3 according to feldspar raw material guide for preliminary classification, provided several types of products capable of being used in the ceramic industry.

\section{REFERNCES}

1. Bender, F., 1974. Geology of Jordan. Gebrueder Borntraeger, Berlin, 196p.

2. Gougazeh, M., 2001. Kaolin and Feldspars Deposits in Jordan: Characterization, Mining, Beneficiation and Upgrading Process Technology, Production and Economic Evaluation for Industrial Utilization. Ph.D. Thesis, Verlag Mainz, Wissenschaftsverlag, Aachen: D 82 Aachen, Techn. Hochsch., Diss., 420p .

3. Konta, J., 1980. Deposits of Ceramic Raw Materials. Ceramic Monographs-Handbook of Ceramics, Monograph 1.1.3, Verlag Shmid Gmbh, Freiburg I Brg.

4. Kotschmidt, P., 1953. Raw Materials for Glass Manufacture, SNTL Prague.

5. Abdel Khalek, N.A. and S.S. Ibrahim, 1994. Beneficiation of Egyptian Feldspar for Application in the Glass and Ceramics Industries. Mineral Engineering. Elsevier Science Ltd., 7: 1193-1201.

6. Wills, B.A., 1997. Mineral Processing Technology. Butterworth Heinemann, Oxford, New York, 486p. 